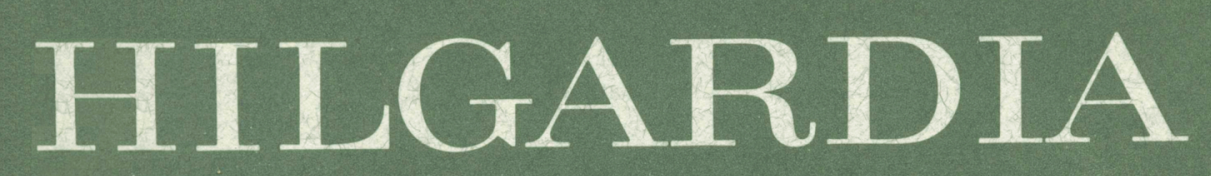

A JOURNAL OF AGRICULTURAL SCIENCE PUBLISHED BY THE CALIFORNIA AGRICULTURAL EXPERIMENT STATION

Volume 46, Number 6 • July, 1978

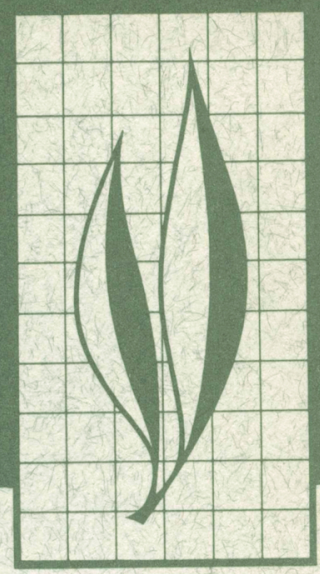

Eutypa armeniacae in Apricot: Pathogenesis and Induction of Xylem Soft Rot

Harley English and J. R. Davis 


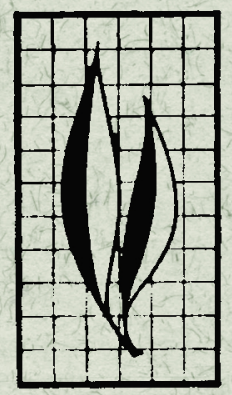

Apricot pruning wounds made at all seasons of the year were susceptible to infection and canker formation resulting from mycelial inoculation with Eutypa armeniacae. Cambial inoculations resulted in comparatively little infection, and inoculations of the inner bark (phloem) were negative. Evidence indicated that the pathogen is inactivated in some infections, and thus sometimes is prevented from forming perennial, girdling cankers. Death of the pathogen did not appear to result from the action of other microorganisms. Invasion of the xylem by $E$. armeniacae resulted in the formation of gum plugs in some of the tracheary elements, and the development of hyphae in the lumens of vessels, fiber-tracheids, and ray parenchyma cells. The hyphae penetrated cell walls directly or through pits. In advanced stages of infection, the hyphae grew longitudinally within the secondary wall, especially of fibertracheids, where, presumably through enzymatic action, they caused the development of soft rot. This soft-rot condition appears to be responsible for the commonly encountered brittle nature of apricot branches killed by this pathogen. The ability of $E$. armeniacae to cause soft rot was demonstrated histologically, and by its capacity to cause weight loss in inoculated birch wood. The softrot phenomenon appears to develop late in the disease syndrone. In vitro studies indicated the ability of the pathogen to produce enzymes that degraded cellulose and xylan. Almond and peach trees were slightly susceptible when wounded tissues were inoculated with mycelia of the fungus.

\section{THE AUTHORS:}

Harley English is Professor of Plant Pathology, University of California, Davis.

J. R. Davis is Professor of Plant Pathology, Idaho Research and Extension Center, Aberdeen, Idaho. 


\section{Eutypa armeniacae in Apricot: Pathogenesis and Induction of Xylem Soft Rot $^{1}$}

\section{INTRODUCTION}

Eutypa armeniacae Hansf. \& Carter (imperfect stage Cytosporina) is a vascular pathogen that causes a serious disease of apricot in California (English et al., 1963), Australia (Adam, 1938; Carter, 1957), and several other apricotproducing countries (Carter, 1972; Carter, Morvan, and Castelain, 1964; Dingley, 1960; and Matthee, Thomas, and Erasmus, 1974). The disease in apricot has been called "gummosis," "Cytosporina dieback," "Eutypa dieback," and "Eutypa canker" (Carter and Bolay, 1972). The pathogen invades wounds, commonly those resulting from pruning, and causes cankers which frequently girdle and kill infected branches (Fig. 1). Affected branches often gum profusely (Fig. 1-C), and after dying usually become quite brittle (Adam, 1938; English et al., 1963).

The pathogen is known commonly to cause disease only in apricot and Ceanothus spp. (Moller, 1964), but it also infrequently causes disease in prune (Carter, 1957), and western chokecherry [Prunus virginiana 'demissa' (Torr. \& Gray) Torr. (English and Davis, 1965) ]. Experimentally, however, ascospores can invade pruning wounds in peach and almond (Carter and Moller, 1971), and mycelia can infect wounds in peach and plum (Carter, 1957; Mat- thee, Thomas, and Erasmus, 1974). There also is evidence that a dying arm disorder of grapevine may be caused by $E$. armeniacae (Moller, Kasimatis, and Kissler, 1974).

Although $\boldsymbol{E}$. armeniacae is a wound pathogen, there is little information on the relative susceptibility of different host tissues to infection. Recent work in California, however, has revealed that sapwood, but not heartwood, is susceptible to ascospore invasion (Ramos, Moller, and English, 1975). Neither the histopathology of the disease nor the nature of the brittle condition of killed apricot branches has been investigated. The latter condition may indicate the presence of a type of wood decay called "soft rot" |Liese, 1970; Savory, 1954), a decomposition not previously associated with a plant pathogen.

This paper presents information on $\mathrm{i}$ ) susceptibility of deciduous fruit trees to infection; ii) the susceptibility of apricot branch tissues of infection; jii) the histopathology of invaded xylem; iv) the longevity of the pathogen in infected branches; and v) the ability of the pathogen to cause soft rot. An abstract covering a portion of this work has been published (English and Davis, $1.965 a)$.

\footnotetext{
${ }^{1}$ Accepted for publication December 1, 1977.
} 


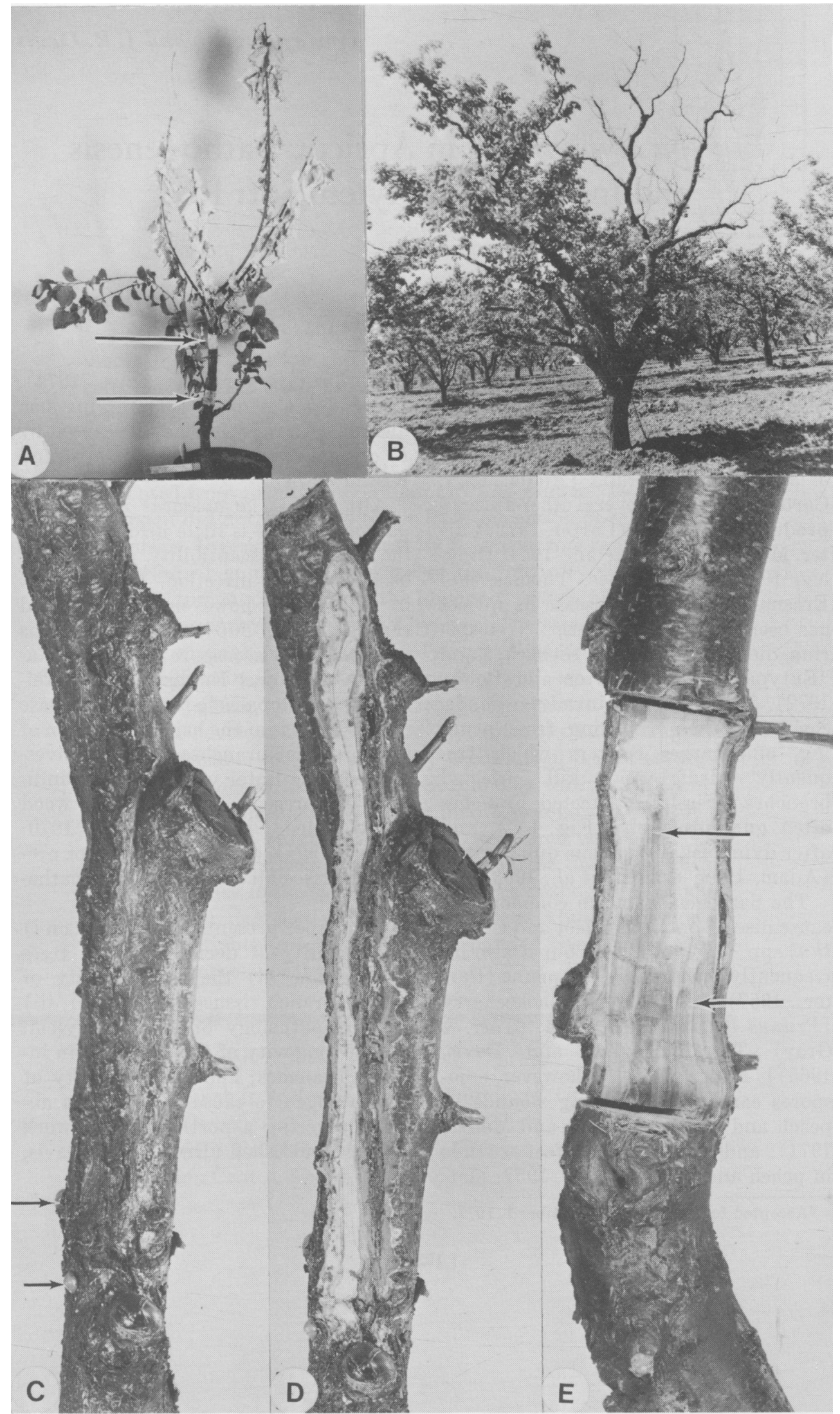




\section{MATERIALS AND METHODS}

\section{Pathogenicity of E. armeniacae}

Pathogenicity tests were conducted with 5- to 6-year-old apricot (Prunus armeniaca $\mathrm{L}$. 'Blenheim') trees growing under standard orchard conditions at Davis, California. Pruning wounds in branches approximately 12 to $15 \mathrm{~mm}$ in diameter were used as inoculation sites. Other inoculations were made at the cambium in holes cut through the bark with a cork borer, and in tangential razor-blade slits cut into the inner bark (phloem). Our isolates 4 and 5 of $E$. armeniacae, previously found to be virulent on apricot, were used in these tests. They were the progeny of hyphaltipped cultures originally isolated from active natural cankers in apricot. The inoculum consisted of $5-\mathrm{mm}$ dises cut from the margin of active petri-dish colonies on potato-dextrose agar (PDA). After the inoculum was placed on the appropriate wound, the inoculation site was covered with polyethylene film and sealed with masking tape. Control inoculations were made with sterile PDA. At the end of the experiments, and following surface disinfestation with $0.5 \% \mathrm{NaOCl}$, reisolations from canker margins were made to confirm the presence of the pathogen. Data on canker length were analyzed by the analysis of variance method.

The comparative susceptibility of deciduous fruit trees to $E$. armeniacae was determined by making cambial and pruning-wound inoculations into 4 - to 6-year-old trees at Davis. The tree and rootstock combinations used were: 'Blenheim' apricot on apricot; 'Nonpareil,' 'Ne Plus Ultra,' and 'Mission' almond on 'Lovell' peach; 'Red Haven' peach on S-37 and 'Lovell'; 'Beauty,' 'Duarte,' and 'President' plum on 'Lovell' and 'Myrobalan'; 'French' prune on 'Lovell' and 'Myrobalan'; 'Bing' cherry on 'Mazzard' and 'Mahaleb'; 'Bartlett' and 'Winter Nelis' pear on pear; and 'Gravenstein' and 'Rome Beauty' apple on apple. The pruning-wound inoculations were made in April, and the cambial inoculations in May. Final assessment of the cambial inoculations was made after 1 year, and of the pruningwound inoculations after 2 years. The isolates and inoculation techniques used were the same as those described above.

\section{Histopathology of infected tissues}

Development and survival of $E$. armeniacae in inoculated (cork-borer inoculations) trunks of 2-year-old, greenhouse-grown 'Blenheim' apricot trees were examined. As these trees developed symptoms, and in some instances were killed, isolations were made from various sites to determine presence of the inoculant; and blocks of tissue were removed for histological examination. After the blocks were boiled in water, sections of 4 - to $10-\mu \mathrm{m}$ thickness were cut from them by means of a sliding microtome. The sections were stained with either cotton blue in lactophenol or

Fig. 1(A-E). Symptoms of Eutypa dieback in 'Blenheim' apricot. A) Young tree inoculated with $\boldsymbol{E}$. armeniacae (mycelial plugs) in cork-borer wounds cut through the bark to the cambium (arrows). Note retention of the withered, discolored leaves on the dead upper portion of the tree above the region of the trunk girdled by the pathogen. B) Mature tree with scaffold branch killed (natural infection) prior to spring foliation. C) Typical depressed, pruning-wound canker with exudation of gum (arrows) along a portion of the canker margin. D) The same canker as in "C" with the outer tissues removed to show the extent of bark necrosis. E) Longitudinal cut through a pruning-wound canker showing the xylem discoloration characteristic of the disease. The apical region of necrosis (upper arrow) generally is sterile, but the pathogen usually can be isolated from the necrotic xylem coextensive with or slightly beyond the bark canker (lower arrow). 
by a Pianeze IIIb procedure. The latter method involved the use of malachite green, $1.0 \mathrm{~g}$; acid fuchsin, $0.5 \mathrm{~g}$; martius gelb, $0.05 \mathrm{~g} ; 95 \%$ ethanol, $50.0 \mathrm{ml}$; and distilled water, $150 \mathrm{ml}$. The stained sections were washed in $95 \%$ ethanol, immersed in the Pianeze stain 10 to 45 min, and washed in distilled water. They were decolorized in acid alcohol, rinsed with $95 \%$ ethanol, and cleared with carbol-turpentine. The carbol-turpentine was removed with xylol, and the sections mounted in balsam. The presence of viable mycelium of the pathogen in artificially and naturally infected apricot trees in the orchard was determined by isolations onto PDA.

\section{Soft-rot studies}

To ascertain whether $E$. armeniacae causes soft rot in apricot, both in vivo and in vitro experiments were performed. The in vivo tests involved the wound inoculation, with mycelial-PDA dises of the pathogen, of orchard or greenhouse-grown apricot trees, and the subsequent histological examination, after periods of several months to 2 years, of the infected xylem. Isolates 4 and 5 of $E$. armeniacae were used in these inoculations.

In the in vitro test, current-season 'Blenheim' apricot branches, free of dieback symptoms, were cut into 12 -cm segments which were inserted into test tubes containing a small amount of distilled water. These tubes were plugged with cotton and autoclaved at 15 psi for 30 min. A PDA disc containing mycelia of the pathogen (isolate 5 ) was placed on the exposed xylem of each tubed branch segment. Segments inoculated with sterile PDA discs served as controls. After the tubes were incubated in the laboratory for 9 months, the branch segments were removed for histological examination.

A further test of the ability of $E$. armeniacae to cause soft rot was made using sterile birchwood (Betula sp.).
Erlenmeyer flasks (1,000-ml) containing 200-ml of PDA each, were sterilized by autoclaving; the medium then was allowed to solidify. Mycelia of known isolates of the pathogen were transferred to the flasks, which then were incubated in the laboratory for 2 weeks to permit the fungus to cover the substrate. Sterile V-shaped glass rods (2 $\mathrm{mm}$ in diameter) were inserted into the flasks and placed on the culture surface. Birch sapwood was cut into blocks $(6 \times$ $25 \times 86 \mathrm{~mm}$ ), numbered with India ink, cleaned of loose wood particles, and weighed daily until they reached constant weight. They were then autoclaved in covered jars, and two of the wooden blocks were transferred aseptically into each flask and laid horizontally on the V-shaped glass rod. Controls consisted of blocks supported in the same manner over sterile PDA. The flasks were then incubated in the laboratory for 3 months. During this period, the blocks above inoculated agar became completely enveloped with mycelia of the pathogen. At the end of the incubation period the blocks were taken out, the mycelia were removed by gentle brushing, and the weights of inoculated and control blocks were recorded. Final dry weights were obtained by holding the blocks in a single layer in an oven at $105 \mathrm{C}$ for $12 \mathrm{~h}$. Four blocks were rerun under the same conditions, and the weights remained constant. These data were used to calculate the loss of weight resulting from decay induced by the pathogen. Thin sections from these blocks were examined microscopically for evidence of soft rot.

\section{Enzyme studies}

The ability of $E$. armeniacae to produce cell-wall-degrading enzymes was determined by growing isolate 5 in shake culture with carbon sources of carboxymethylcellulose or xylan (Commercial xylan, Nutritional Biochemical Corp., Cleveland, Ohio). The culture 
medium consisted of $2 \mathrm{~g}$ L-asparagine, $0.75 \mathrm{~g} \mathrm{MgSO}_{4} \cdot 7 \mathrm{H}_{2} \mathrm{O}, 1.25 \mathrm{~g} \mathrm{KH}_{2} \mathrm{PO}_{4}$, $2.0 \mathrm{~g}$ of the appropriate carbon source, and $1000 \mathrm{ml}$ of deionized water. The cultures were incubated 22 days at laboratory temperature. The mycelia were removed by filtration and discarded. The extracts were then dialyzed against distilled water for 2 days at $4 \mathrm{C}$.

The dialyzed extracts (material retained within the dialysis sacks) were assayed in reaction mixtures containing: $20 \mathrm{mg}$ of pure Whatman cellulose or washed xylan (washed once in $80 \%$ ethanol, twice in $100 \%$ ethanol, once with anhydrous ether, and then air dried), $2 \mathrm{ml}$ of the appropriate culture extract, and $1.0 \mathrm{ml}$ of $0.1 \mathrm{M}$ acetate buffer at $\mathrm{pH}$ 5.2. The reactions were run in triplicate. Controls consisted of $i)$ the extract (enzyme) without the substrate; ii) the substrate without the extract; and iii) the heat-inactivated $(100 \mathrm{C}$, $10 \mathrm{~min}$ ) extract with the substrate. The reaction mixtures were incubated under toluene for $16 \mathrm{~h}$ at laboratory temperature (approximately $23 \mathrm{C}$ ). The reactions were terminated by heating at $100 \mathrm{C}$ for $10 \mathrm{~min}$. Portions $(3 \mathrm{ml})$ from the respective mixtures were concentrated to air-dryness, dissolved in a drop of deionized distilled water, and spotted on Whatman \#1 filler paper for chromatographic analysis. The chro- matograms were developed in a butanol:acetic acid:water $(4: 1: 5 \mathrm{v} / \mathrm{v})$ solvent system for $43 \mathrm{~h}$ dried, and sprayed with $\mathrm{AgNO}_{3}$ and $\mathrm{NaOH}$ to detect reducing sugars formed in the enzyme assay mixtures (Trevelyan, Procter, and Harrison, 1950). Identification of unknown compounds was accomplished by spotting appropriate internal standard compounds on the same chromatogram with the unknowns. Thus, glucose and cellobiose were used in the cellulose degradation determinations, and xylopentaose, xylotetraose, xylotriose, xylobiose, xylose, glucose, and arabinose in the determinations with xylan. (The xylopentaose, xylotetraose, xylotriose, and xylobiose were kindly contributed by G. A. Strobel.)

A second set of the same culture extract reaction mixtures and controls, as used for the chromatographic analyses described above, was prepared for quantitative determinations of enzyme activity. The extract-cellulose and extract-xylan mixtures were incubated under toluene at room temperature for $16 \mathrm{~h}$, then analyzed for reducing sugar by the Nelson technique (Nelson, 1944), using glucose as a standard. A unit of xylanase or cellulase activity is defined as a $\mu$ mole of reducing sugar (glucose standard) formed per $h$ per ml under the conditions described above.

\section{RESULTS}

\section{Susceptibility of deciduous fruit trees to $E$. armeniacae}

Of 14 stone and pome fruit cultivars inoculated at pruning wounds, only apricot, peach, and almond had indications of susceptibility to $E$. armeniacae (Table 1). 'Red Haven' peach, and 'Nonpareil' and 'Ne Plus Ultra' almond, had infection percentages comparable to that in 'Blenheim' apricot. Canker development in the latter, however, was considerably greater than that in almond and peach. The pathogen was re- isolated from cankered tissue of apricot, peach, and one of the almond cultivars 2 years after inoculation.

Cambial inoculations resulted in canker development only in 'Blenheim' apricot and 'Ne Plus Ultra' and 'Mission' almond. One year after inoculation the cankers appeared inactive, and most were surrounded by healthy callus tissue.

Stone and pome fruit cultivars that failed to develop cankers when inoculated at either the cambium or pruning 
TABLE 1

SUSCEPTIBILITY OF PRUNING WOUNDS OF STONE-FRUIT TREES TO INFECTION AND CANKER DEVELOPMENT BY EUTYPA ARMENIACAE

\begin{tabular}{lccc}
\hline \hline & & Condition 2 years after inoculation \\
\cline { 2 - 4 } Tree inoculated & Infection & $\begin{array}{c}\text { Mean canker } \\
\text { length* }\end{array}$ & $\begin{array}{c}\text { Reisolation } \\
\text { of pathogen }\end{array}$ \\
\hline & percent & $m m$ & Positive \\
Blenheim apricot & 88 & 128 & Positive \\
Red Haven peach & 80 & 53 & Positive \\
Nonpareil almond & 100 & 51 & 78 \\
Ne Plus Ultra almond & 100 & Negativet & \\
\hline
\end{tabular}

* Mean canker lengths were determined by deducting the mean dieback in the controls from the dieback in inoculated branches.

† The pathogen was reisolated from cankers 1 year after inoculation.

wounds were 'Bing' cherry; 'Beauty,' 'Duarte,' and 'President' plum; 'French' prune; 'Bartlett' and 'Winter Nelis' pear; and 'Gravenstein' and 'Rome Beauty' apple.

\section{Susceptibility of apricot branch tissues to infection}

Fresh pruning wounds, where the inoculum was placed on the xylem, were highly susceptible to infection and canker development regardless of the time of year (Table 2). Cambial inoculations, however, resulted in low infection levels and relatively little canker formation. Inner bark (phloem) inoculations resulted in no infection. Cankers resulting from xylem inoculation were significantly $(P=0.05)$ larger than those initiated at the cambium. Two years after inoculation, most pruning-wound cankers had continued enlargement, whereas some cambial cankers had little if any increase in size after the first year, and were surrounded by healthy wound callus.

\section{Survival of the pathogen in diseased apricot tissues}

Field observations and isolations from typical Eutypa cankers in apricot branches indicated that some cankers may become inactive, and that the pathogen may not be recoverable from the infected tissues of these cankers. More than 700 isolations were made from naturally occurring, typical Eutypa cankers collected from apricot orchards in Santa Clara and Yolo counties. Some of these cankers appeared

TABLE 2

EFFECTS OF DATE AND TYPE OF INOCULATION ON INFECTION AND CANKER DEVELOPMENT IN APRICOT BY EUTYPA ARMENIACAE*

\begin{tabular}{|c|c|c|c|c|c|}
\hline \multirow[b]{3}{*}{$\begin{array}{l}\text { Date of } \\
\text { inoculation }\end{array}$} & \multicolumn{5}{|c|}{ Inoculation of } \\
\hline & \multicolumn{2}{|c|}{ Xylemt } & \multicolumn{2}{|c|}{ Cambium } & \multirow{2}{*}{$\begin{array}{l}\text { Inner bark } \\
\text { Infection }\end{array}$} \\
\hline & Infection & $\begin{array}{l}\text { Canker } \\
\text { length }\end{array}$ & Infection & $\begin{array}{l}\text { Canker } \\
\text { length }\end{array}$ & \\
\hline & percent & $m m$ & percent & $m m$ & percent \\
\hline 19 January & 88 & 41 & 25 & 8 & 0 \\
\hline 24 May & 88 & 41 & 13 & 3 & 0 \\
\hline 14 August & 88 & 53 & 0 & 0 & 0 \\
\hline 1 November & 100 & 52 & 25 & 13 & 0 \\
\hline
\end{tabular}

* Data recorded 1 year after each inoculation date. Canker lengths represent the means of eight inoculations. $\uparrow$ Xylem inoculations were made at fresh pruning wounds. Cankers resulting from these inoculations were significantly $(P=0.05)$ larger than those initiated at the cambium. 
active, whereas others had healthy marginal callus and appeared inactive. The isolations were made from all of the affected (discolored) tissues of the bark and wood, including dark streaks in the xylem that sometimes extended 30 to $50 \mathrm{~cm}$ beyond the apices of the cortical cankers. The fungus was recovered from only about half of the cankers sampled, and mainly from those that had evidence of activity. Cankers that were negative for the pathogen were either sterile or yielded one or more unidentified fungi, none of which, upon wound inoculation, proved pathogenic to apricot branches. Also, none of these isolates was inhibitory to the growth of $E$. armeniacae on PDA. In cankers that contained $E$. armeniacae, the pathogen could generally be isolated from necrotic phloem and xylem coextensive with the canker (Fig. 1-E). It was not recovered from discolored xylem more than $20 \mathrm{~mm}$ beyond the margin of the canker, or from nondiscolored tissues adjacent to the affected area.

Artificially induced cankers resulting from inoculation of 'Blenheim' apricot trees with isolates 4 and 5 of $E$. armeniacae, in the orchard, generally yielded the pathogen on isolation from bark and xylem coextensive with the canker. One 4-cm diameter branch inoculated at the cambium with isolate 5 provided interesting results. After death of the branch 2 yr after inoculation, histological examination revealed that the fungus had invaded both the bark and wood in the girdled and killed area, and soft rot was evident in the xylem. The pathogen, however, could be reisolated only from the infected bark and xylem near the lower advancing margin of the canker. It could not be recovered from host tissues that had been dead for some time.

Similar inoculations with isolate 4 into 2-year-old 'Blenheim' trees in the greenhouse provided additional information on survival of the pathogen in infected tissues. Some of the inoculations were made into the trunks, and others into succulent shoots. Within a few months, elliptic cankers, 3 to $5 \mathrm{~cm}$ in length, had developed from many of the inoculations. Examination of the cankers 1 yr after inoculation revealed that most had ceased to enlarge, and some had been completely healed with healthy callus. Although over 300 isolations were made from necrotic bark and xylem associated with these cankers, $E$. armeniacae was recovered only nine times. It appears, therefore, that not all infections of apricot trees by $E$. armeniacae result in the formation of perennial cankers that cause girdling and death of the affected branch or trunk.

\section{Histopathology and the development of soft rot}

Inoculation of $E$. armeniacae into apricot via pruning or cork-borer wounds resulted, within a few months, in a brownish discoloration of the xylem (Fig. 2-A). Dark-colored gum plugs were evident in some of the tracheary elements, and hyphae of the pathogen were present in the lumens of vessels, fiber-tracheids, and ray parenchyma cells. The hyphae penetrated cell walls directly or through pits. In advanced stages of infection, the hyphae penetrated the secondary walls, especially of fiber-tracheids, where they grew longitudinally within the wall and, presumably through enzymatic action, caused the development of soft rot. The soft-rot cavities in the secondary wall were elongate with conical ends, as seen in longitudinal section, and circular in cross section (Fig. 2-B). This type of cell wall destruction is characteristic of soft rot of wood in service-structural wood subjected to natural biotic and abiotic environmental factors (Duncan, 1960; Levy, 1965; Liese, 1970; and Savory, 1954).

The brittle nature of apricot branches 


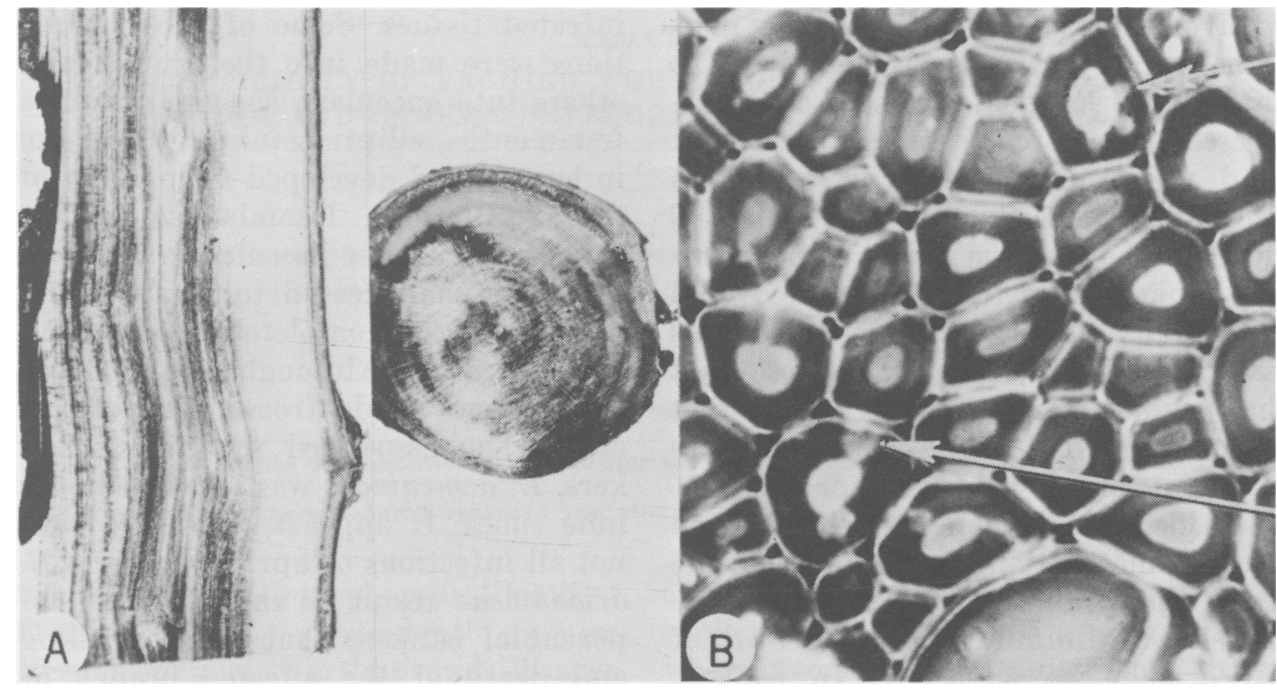

Fig. 2(A, B). Apricot branch tissues infected with Eutypa armeniacae. A) Cross and longitudinal sections of a Blenheim apricot branch showing the typical xylem discoloration associated with infection. Right side of longitudinal section shows healthy xylem, cambium, and cortex. B) Soft-rot cavities (indicated by arrows) in the secondary wall of fiber-tracheids.

killed by $\boldsymbol{E}$. armeniacae strongly indicated the presence of soft rot in the xylem (Liese, 1970; and Savory, 1954). Evidence that this fungus causes soft rot was obtained, as mentioned above, from a histological examination of infected xylem resulting from artificial inoculation of apricot branches or trunks in both the orchard and the greenhouse. These studies, however, did not eliminate the possibility that a secondary organism might actually have caused the soft rot. Conclusive evidence that $E$. armeniacae causes the soft-rot condition in apricot was obtained from the inoculation of sterile branch segments held in test tubes under axenic conditions. Histological examination of these segments 9 months after inoculation, revealed typical soft-rot decomposition of the secondary wall of fibertracheids.

The ability of $E$. armeniacae to cause wood decay was further substantiated by the inoculation of sterile sapwood blocks of birch. After incubation of these blocks for 3 months, they had a weight loss of approximately $10 \%$, a significant difference from that of the controls (Table 3). Histological examination of the decayed wood revealed typical symptoms of soft rot.

\section{Production of cell-wall-degrading enzymes by $E$. armeniacae}

Eutypa armeniacae was grown, as explained above, in liquid culture with carbon sources of carboxymethylcellulose or xylan. Dialyzed extracts from these cultures were then mixed with selected substrates to determine the presence of hydrolytic enzymes. When the carboxymethylcellulose culture extract was mixed with pure cellulose and then chromatographed, spots with $\mathrm{Rf}$ values identical to those of glucose and cellobiose were obtained. Controls had no spots in these positions. Culture filtrates contained 0.03 unit cellulase activity per $\mathrm{ml}$. It is evident, that, in vitro, the fungus produces cellulolytic enzymes in low concentration.

When the xylan culture extract was mixed with washed xylan and then 
TABLE 3

WEIGHT LOSS OF BIRCH BLOCKS INOCULATED WITH ISOLATES OF EUTPPA $A R M E N I A C A E$ AND INCUBATED IN THE LABORATORY FOR 3 MONTHS*

\begin{tabular}{|c|c|c|c|}
\hline \multirow[b]{2}{*}{ Isolate } & \multicolumn{2}{|c|}{ Oven-dry weight } & \multirow{2}{*}{$\begin{array}{c}\text { Mean weight } \\
\text { loss }\end{array}$} \\
\hline & Initial & Final & \\
\hline $\mathbf{3}$ & 9.28 & 8.40 & $\begin{array}{c}\text { percent } \\
\quad 9.5\end{array}$ \\
\hline 4 & 9.65 & 8.70 & 9.8 \\
\hline 5 & 9.74 & 8.73 & 10.1 \\
\hline 6 & 9.79 & 8.90 & 9.1 \\
\hline
\end{tabular}

* Four single-block replicates were inoculated with each isolate and incubated at approximately $22 \mathrm{C}$.

$\dagger$ All means differed significantly from the control at $\boldsymbol{P}=0.01$ (analysis of variance).

chromatographed, spots were developed with $R f$ values identical to those of xylopentaose, xylotetraose, xylotriose, xylobiose, glucose, arabinose, xylose, and two unknown compounds. The controls had no evidence of spots in any of these positions. Culture filtrates had 0.18 unit of xylanase activity per $\mathrm{ml}$.

\section{DISCUSSION}

Of 14 stone and pome fruit cultivars inoculated, only apricot, almond, and peach developed canker or dieback symptoms. The lesions in almond and peach tended to be smaller than those in apricot, and most developed healthy marginal wound callus 1 to 2 years after infection. Although the pathogen could be reisolated from most of these infections at this time, there was no evidence that it could continue its invasiveness and cause extensive dieback in hosts other than apricot. These results support those of Carter and Moller (1971), who reported that although infection could occur in almond, peach, and prune, the pathogen had little or no capacity to cause canker or dieback symptoms in these hosts. Work in South Africa (Matthee, Thomas, and Erasmus, 1974) revealed that $E$. armeniacae could induce cankers in apricot, peach, and plum, but dieback symptoms were reported only for apricot. Observations in our experimental orchard at Davis, and in several commercial orchards, confirmed our belief that apricot is the only commercially grown deciduous fruit tree susceptible to this pathogen under California conditions. Apricot trees heavily infected with $\boldsymbol{E}$. armeniacae have been observed in close proximity to trees of other stone fruits, almonds, and pome fruits, none of which had evidence of infection. Similar observations with regard to natural infection of Prunus species have been reported from Australia (Carter and Moller, 1971).

Eutypa armeniacae has long been known as a wound pathogen of apricot trees, and Adam (1938) provided some evidence that xylem must be exposed in order for infection to occur. Carter (1960) showed that injured xylem is susceptible to ascospore infection; and recent work in California (Ramos, Moller, and English, 1975) has revealed that sapwood, but not heartwood, is susceptible to infection by ascospores. This latter study did not include inoculation of other host tissues. Our research supports that of Adam in revealing that freshly injured xylem is highly susceptible to mycelial infection, and that the inner bark (phloem) is immune to infection. We also found that the cambium is much less susceptible to infection, as measured by canker development, than the xylem. Fresh xylem wounds appeared to be almost uni- 
formly susceptible to infection regardless of the season of the year when the inoculations were made. Ramos, Moller, and English (1975), however, have shown that spring pruning wounds remain susceptible to ascospore infection for a shorter period than those made in autumn or winter. Although in nature ascospores comprise the principal inoculum, it is entirely possible that small, mycelium-containing saw chips carried on pruning tools could play a role in infection, as Adam (1938) suggested.

The present study is the first to examine the histopathology of the dieback disease of apricot caused by $E$. armeniacae. We have found that the pathogen initially colonizes the xylem, typically that exposed by pruning, where it readily grows within the lumens of both living and dead xylem elements. The hyphae penetrate cell walls either directly or through pits, and, in advanced infections, grow longitudinally within the secondary wall of some xylem elements, thereby causing the type of wood decay defined as soft rot. After colonization of the xylem, the pathogen kills the cambium and then invades and kills the phloem and other cortical tissues, to produce a canker. Under field conditions, however, cankers may not be visible until 1 to 2 yr after infection. The xylem may be discolored for a distance of $20 \mathrm{~cm}$ or more above and below the canker margin. Isolations and histological examinations indicate that most of this discolored xylem beyond the canker margin does not harbor the pathogen. The discoloration may indicate the longitudinal movement within the xylem of toxic metabolites produced by the pathogen. The death of a large apricot branch may not occur until several years after infection, and not, apparently, until the pathogen has completely colonized the functional xylem of at least a portion of the branch. Death of branches commonly occurs during summer when the transpiration rate is high, and appears to be due largely to occlusion of the tracheary elements by gum plugs.

Our preliminary report (English and Davis, 1965) that $E$. armeniacae causes the soft-rot type of decomposition of the wood of apricot branches appears to be the first record of the association of xylem soft rot with a plant disease. More recently, however, Foster and Marks (1968) showed that Diplodia pinea, a conifer pathogen, causes soft rot in Pinus radiata. Umezurike (1969) reported that Botryodiplodia theobromae, a weakly pathogenic "stain" fungus, is able to cause soft rot in harvested wood of B'ombax buonopozense. In in vitro tests (Casagrande and Ouellette, 1971), Ceratocystis ulmi induced soft rot in beech wood, although this decomposition apparently was not observed in infected elm trees. Another plant pathogen, Coniothyrium fuckelii, also is reportedly (Levy, 1965) able to cause soft rot under in vitro conditions. Most of the fungi known to induce soft rot are saprobes classified within either the Ascomycetes or the Fungi Imperfecti (Duncan, 1960; Levy, 1965). However, from our study and that of Foster and Marks (1968), it appears probable that soft rot will be found in additional canker or vascular diseases of woody plants.

Our conclusion that $E$. armeniacae causes soft rot of the wood of infected apricot branches is based on several lines of evidence. Apricot branches killed by this pathogen usually become brittle, a characteristic of wood affected with soft rot (Savory, 1954). The secondary wall of fibertracheids develops cavities typical of those formed in wood affected with soft rot (Duncan, 1960; Liese, 1970; Savory, 1954). The pathogen causes a weight loss of inoculated birch wood blocks similar in magnitude to that caused by some known soft-rot fungi (Duncan, 1960; Eslyn, Kirk, and Effland, 1975). It probably accom- 
plishes this decay by the production of exoenzymes which degrade cellulose and hemicellulose (mostly xylan), the two principal components of the secondary wall (Cowling, 1961).

Soft rot appears to develop somewhat after the initial phase of pathogenesis, and it is not known whether the exoenzymes responsible for this condition play an active role in pathogenesis per se. These enzymes, which appear to be exuded mainly from the apical region of hyphae (Liese, 1970), could conceivably play a part in cell wall penetration of both living and dead cells.

In the present study there was an apparent tendency of $\boldsymbol{E}$. armeniacae to die in part or all of the infected tissues of some apricot branch infections. This phenomenon was observed in both natural and artificially induced infections in the field and in greenhouse inoc- ulatons. These results may explain, in part, the paucity of the sexual stage of the pathogen in the warmer and drier portions of California. This stage, a perithecial stroma, develops on decorticated apricot wood (or occasionally on other woody substrates) several years after infection (Carter, 1957, 1960). It is not known whether death of the pathogen is due to unfavorable temperature or moisture conditions, or both, or to the possible accumulation of toxic metabolites in the infected tissues. Since the pathogen invades the heartwood as well as the outer tissues, death would not appear to result from an active defense mechanism of the host. Also, our results indicate that failure to recover the pathogen from some cankers probably is not due to antibiosis by other microorganisms.

\section{ACKNOWLEDGMENTS}

The authors gratefully acknowledge Strobel in certain aspects of this investhe helpful advice of $\mathrm{R}$. N. Campbell, tigation. J. E. DeVay, T. Kosuge, and G. A.

\section{LITERATURE CITED}

ADAM, D. B.

1938. A progress report on a gummosis (dieback) disease in South Australian apricot trees. J. Dep. Agric. S. Aust. 42:14-29.

Carter, M. V.

1957. Eutypa armeniacae Hansf. \& Carter sp. nov., an airborne vascular pathogen of Prunus armeniaca L. in southern Australia. Aust. J. Bot. 5:21-35.

1960. Further studies on Eutypa armeniacae Hansf. \& Carter. Aust. J. Agric. Res. 11:498-504.

CARTER, M. V., and A. Bolay

1972. Eutypa dieback of apricot is prevalent in Switzerland. Phytopathol. Z. 75:187-89.

CARTER, M. V., and W. J. Moller

1971. The quantity of inoculum required to infect apricot and other Prunus species with Eutypa armeniacae. Aust. J. Exp. Agric. Anim. Husb. 11:684-86.

Carter, M. V., G. S. Morvan, and C. Castelain

1964. An extension of the known distribution of Eutypa armeniacae. Nature (Lond.) 202: 1134-35.

Casagrande, F., and G. B. Ouellette

1971. A technique to study the development in wood of soft rot fungi and its application to Ceratocystis ulmi. Can. J. Bot. 49:155-59.

Cowling, E. B.

1961. Comparative biochemistry of the decay of sweetgum sapwood by white-rot and brownrot fungi. U. S. Dep. Agric. Tech. Bull. 1258. 79 pp.

Dingley, J. M.

1960. Eutypa canker of apricots. Orchardist N.Z. 33(3) :78-79. 
Duncan, C. G.

1960. Wood-attacking capacities and physiology of soft-rot fungi. U. S. For. Serv. For. Proc. Lab. Rep. 2173. 70 pp.

English, H., and J. R. Davis

1965a. Pathogenic activity of Eutypa armeniacae in apricot. Phytopathology 55:1057. (Abstr.). 1965b. Apricot dieback fungus found on western choke-cherry. Plant Dis. Rep. 49:178.

English, H., H. J. O’Reilly, L. B. McNelly, J. E. DeVAy, and A. D. Rizzi

1963. Cytosporina dieback of apricot. Calif. Agric. 17(2):2-4.

EsLYN, W. E., T. K. KIRK, and M. J. EFFLAND

1975. Changes in the chemical composition of wood caused by six soft-rot fungi. Phytopathology 65:473-76.

Foster, R. C., and G. C. MARKs

1968. Fine structure of the host-parasite relationship of Diplodia pinea on Pinus radiata.

LEVY, J. Aust. For. 32:211-25.

1965. The soft rot fungi: the mode of action and significance in the degradation of wood. Adv. Bot. Res. 2:323-57.

LIESE, W.

1970. Ultrastructural aspects of woody tissue disintegration. Annu. Rev. Phytopathol. 8: 231-58.

Matthee, F. N., A. C. Thomas, and A. D. Erasmus

1974. Die-back of apricot trees in South Africa caused by Eutypa armeniacae. Phytophylactica 6:131-32.

MOLLER, W. J.

1964. Apricot disease found on garden shrub. J. Agric. S. Aust. 67:251.

MOLLER, W. J., A. N. Kasimatis, and J. J. KISSLER

1974. A dying arm disease of grape in California. Plant Dis. Rep. 58:869-71.

Nelson, N.

1944. A photometric adaptation of the Somogyi method for the determination of glucose. J. Biol. Chem. 153:375-80.

RAmos, D. E., W. J. Moller, and H. ENGLish

1975. Susceptibility of apricot tree pruning wounds to infection by Eutypa armeniacae. Phytopathology 65:1359-64.

SAvory, J. G.

1954. Breakdown of timber by Ascomycetes and Fungi Imperfecti. Ann. Appl. Biol. 41:336-47.

Trevelyan, W. E., D. P. Procter, and J. S. Harrison

1950. Detection of sugars on paper chromatograms. Nature 166:444-45.

UMEZURIKE, G. M.

1969. Cellulolytic activities of Botryodiplodia theobromae Pat. Ann. Bot. (Lond.) 33:451-62. 
The journal HILGARDIA is published irregularly. Number of pages and number of issues vary per annually numbered volume. Address: Agricultural Sciences Publications, Division of Agricultural Sciences, University of California, Berkeley, CA 94720. 